\title{
Terapi rasional-emotif perilaku untuk menurunkan tingkat depresi pada wanita
}

$\Psi$ PROCEDIA Studi Kasus dan Intervensi Psikologi p-ISSN 2302-1462; e-ISSN 2722-7669 ejournal.umm.ac.id/index.php/procedia 2021, Vol 9(4):138-144

DOI:10.22219/procedia.v9i4.16328

(C) The Author(s) 2021

()(i) 4.0 International license

\section{Andita Faradilla ${ }^{1}$}

\begin{abstract}
The subject is a college student woman who has changes in functionality in everyday life. Subject has a bad view of herself and tend to like to compare herself with others, especially physical problems. As a result, subject tend to be easily sad, lose interest, often feel tired and sometimes bring up suicidal thoughts. The assessment methods used were clinical interview, observation, and psychological tests, namely the Weschler Adult Intelligence Scale, graphics, Thematic Apperception Test, the Beck Depression Inventory II scale and WHODAS. Subject was diagnosed with major depressive disorder with moderate level of functioning. The intervention used was rational-emotive behavior therapy which was composed of five sessions. This therapy is used with the aim of reducing depression levels through changing irrational beliefs to become more rational. The results of the intervention showed a decrease in the subject's level of depression as indicated by changes in the scores obtained before and after the intervention was given.
\end{abstract}

\section{Keywords}

Adult women, depression, rational-emotive therapy

\section{Pendahuluan}

Gangguan depresi mayor merupakan gangguan dengan kemunculan setidaknya satu episode depresi mayor tanpa adanya riwayat mania atau hipomania. Episode depresi mayor melibatkan perubahan yang signifikan secara klinis dalam fungsionalitas seseorang yang melibatkan serangkaian simtom depresif, termasuk suasana hati depresi (merasa sedih, tidak punya harapan, atau terpuruk) dan/atau hilangnya minat atau kesenangan dalam semua atau hampir semua aktivitas paling tidak selama dua minggu (American Psychiatric Association, 2013). Depresi mayor adalah masalah kesehatan publik yang utama, tidak hanya memengaruhi fungsi psikologis seseorang, tetapi juga melumpuhkan kemampuan seseorang untuk memenuhi tanggung jawab sekolah, pekerjaan, keluarga, dan sosial (Forgeard et al,, 2012; Pratt \& Brody, 2008).

Gejala depresi mayor pada subjek penelitian ini yaitu sering merasa sedih, kosong, putus asa, penurunan motivasi dan minat dalam beraktivitas, sering merasa lelah, merasa tidak berharga, serta memiliki pikiran bunuh diri. Hal tersebut dikarenakan subjek sangat ingin memiliki kekasih namun tidak kunjung ia dapatkan.

Erikson berpendapat bahwa usia 20-40 tahun merupakan tahap keintiman atau keakraban versus keterasingan atau kesendirian. Pada tahap ini, kekuatan dasar yang dibutuhkan ialah "kasih" karena muncul konflik antara keintiman atau keakraban versus keterasingan atau kesendirian (Chung, 2018). Agen sosial pada tahap ini ialah kekasih, suami atau istri termasuk juga sahabat yang dapat membangun suatu bentuk persahabatan sehingga tercipta rasa cinta dan kebersamaan. Bila kebutuhan ini tidak terpenuhi, maka muncul perasaan kesepian, kesendirian dan tidak berharga.

Berdasarkan teori ABC Albert Ellis dijelaskan bahwa keyakinan irasional yang dimiliki individu tentang masalahnya menumbuhkan emosi negatif dan perilaku maladaptif (Corey, 2013). Subjek dalam penelitian ini menuntut dirinya harus mendapatkan kekasih namun ketika ia tidak mendapatkannya, ia merasa fisik yang kurang menarik adalah penyebab laki-laki tidak menyukainya. Subjek juga sering membandingkan dirinya dengan orang lain dan mempertanyakan mengapa temannya yang tidak lebih menarik dari dirinya dan adiknya bisa berganti-ganti pasangan. Keyakinan irasional subjek tersebut dapat diubah menjadi keyakinan yang lebih rasional menggunakan terapi rasional-emotif perilaku.

Terapi rasional-emotif perilaku memunculkan perubahan yang lebih mendalam dibandingkan terapi kognitif karena a) dapat membuat klien menerima dirinya tanpa

\footnotetext{
${ }^{1}$ Universitas Muhammadiyah Malang, Indonesia
}

Korespondensi:

Andita Faradilla, Direktorat Program Pascasarjana, Universitas Muhammadiyah Malang, Jl. Tlogomas 246 Malang, Indonesia Email: anditafdilla18@gmail.com 
syarat; b) mengurangi masalah sekunder, seperti mengkritisi diri sendiri karena memiliki masalah; dan c) fokus pada sikap klien yang selalu menuntut dirinya yang merupakan keyakinan dasar pada kasus depresi (David et al., 2005). Oleh karena itu, subjek perlu diberikan penanganan untuk mengurangi bahkan mengganti keyakinan irasionalnya menjadi keyakinan rasional sehingga subjek bisa menerima dirinya tanpa syarat menggunakan terapi rasional-emotif perilaku menurut konsep Albert Ellis (Corey, 2013).

\section{Metode Asesmen}

Metode asesmen yang digunakan adalah wawancara klinis, observasi dan beberapa tes psikologi. Wawancara klinis dilakukan dengan tujuan guna mengumpulkan informasi secara mendalam terkait dengan keluhan sehingga nantinya akan memudahkan dalam membuat psikogenesa dan menegakkan diagnosis. Wawancara dilakukan pada subjek dan perwakilan anggota keluarga.

Selanjutnya, observasi dilakukan dengan tujuan untuk melihat kondisi subjek saat wawancara dan taraf keberfungsiannya sehingga akan berguna dalam perancangan intervensi. Tes psikologi yang digunakan mencangkup tes intelegensi yaitu Weschler Adult Intelligence Scale (WAIS), untuk mengetahui kapasitas intelektual guna memprediksi seberapa jauh pemahaman subjek terhadap intervensi yang akan diberikan dan melihat patologis yang ada pada diri subjek. Asesmen juga menggunakan tes kepribadian yakni tes grafis (DAP, BAUM, HTP) yang bertujuan untuk mengungkap kepribadian dan konsep diri subjek secara mendalam. Thematic Apperception Test (TAT) bertujuan untuk mengungkap dinamika kepribadian dalam hubungan interpersonal, dorongan emosi, serta konflik pribadi yang dominan dalam diri subjek. Beck Depression Inventory (BDI-II), yang telah diterjemahkan dalam Bahasa Indonesia oleh Kurniawan \& Noviza (2017) sebagai data pendukung untuk mengukur tingkat depresi subjek pada saat sebelum dan sesudah intervensi, dengan reliabilitas skala sebesar 0,902 (Kurniawan \& Noviza, 2017). Kemudian, juga digunakan World Health Organization Disability Assessment Schedule (WHODAS) yang bertujuan untuk mengetahui taraf keberfungsian subjek sebagai pertimbangan intervensi dan prognosis.

\section{Presentasi Kasus}

Subjek merupakan seorang perempuan berusia 24 tahun yang saat ini sedang menempuh semester akhir di bangku kuliah dan anak pertama dari empat bersaudara. Saat ini, subjek tinggal dengan adik keduanya di sebuah koskosan. Orangtua subjek tinggal di kota berbeda. Hubungan orangtua subjek tidak begitu harmonis. Subjek merupakan anak di luar pernikahan dan ayah subjek cenderung meragukan bahwa ia merupakan anak kandungnya. Sejak usia dua tahun, subjek sudah dititipkan pada neneknya dengan alasan punya adik sehingga orangtuanya sibuk mengurusi adiknya tersebut. Subjek secara fisik memiliki perawakan yang lebih berisi dengan kulit berwarna kecoklatan dan memiliki skor IQ 92 dengan kategori rata-rata. Sejak kecil kondisi fisik tersebut menjadi perbandingan bagi orangtua dan lingkungan sekitarnya sehingga membuat subjek menumbuhkan perasaan negatif terhadap kondisi fisiknya tersebut.

Subjek menyatakan bahwa saat ini ia sangat ingin memiliki kekasih yang bisa menyayangi dan menyemangatinya namun tidak kunjung mendapatkannya. Kondisi ini mendorong subjek untuk berusaha melakukan berbagai cara agar mendapatkan kekasih. Subjek pernah memiliki kekasih saat akhir masa SMK namun kekasihnya merupakan seorang homoseksual dan diketahuinya setelah beberapa bulan menjalin hubungan. Subjek berusaha bertahan dengan kekasihnya karena berharap kekasihnya bisa berubah namun pada akhirnya hubungan mereka berakhir. Saat kuliah ia sudah beberapa kali menyukai lelaki namun tidak ada satupun yang menjadi kekasihnya. Subjek bahkan pernah berkenalan dengan seorang lakilaki selama tiga atau empat hari dan langsung melakukan hubungan seksual dengan laki-laki tersebut tanpa memiliki status resmi. Berbagai cara yang telah dilakukan oleh subjek tersebut tetap saja tidak membuatnya mendapatkan kekasih. Akhirnya, subjek merasa sangat menyesal, sedih, bahkan pernah mencoba bunuh diri namun tidak jadi ia lakukan karena dicegah oleh temannya.

Subjek selalu menuntut dirinya untuk segera mendapatkan kekasih sehingga selalu merasa buruk ketika tidak bisa memenuhi tuntutan tersebut. Subjek merasa bahwa fisiknya yang kurang menarik (tubuh gemuk dan kulit coklat) merupakan alasan laki-laki tidak ada yang ingin menjadi kekasihnya. Hal ini mendorong subjek untuk sering membandingkan dirinya dengan orang lain yaitu teman-temannya dan juga adiknya yang menurut subjek tidak lebih menarik darinya. Akhirnya kondisi tersebut membuat subjek sering merasa sangat sedih, kosong, tidak punya harapan, merasa tidak berharga, sulit berkonsentrasi dan sulit mengambil keputusan, sering merasa lelah, penurunan motivasi atau minat dalam melakukan kegiatan yang biasanya ia senangi, dan beberapa kali berpikir bunuh diri setiap laki-laki yang ia sukai menjauh.

Selain itu, subjek juga mulai merokok untuk menghilangkan kesedihannya. Meskipun demikian ia tetap berusaha menjalani kehidupan dengan normal. Ia juga sempat bekerja di kedai kopi namun berhenti karena ingin fokus dengan skripsi dan kondisi emosi subjek saat itu sedang tidak stabil diakibatkan oleh rasa sedih dijauhi oleh laki-laki yang ia sukai. Subjek memiliki kebutuhan yang tinggi akan kasih sayang namun ia tidak mendapatkannya baik dalam konteks romantis maupun konteks keluarga. Ia juga merasa tidak percaya diri dengan kondisi fisiknya. Subjek merupakan akan cenderung menghindar, pasif, dan tidak memiliki pemecahan masalah yang baik ketika berhadapan dengan masalah. Hal ini yang membuat subjek cenderung mudah untuk memunculkan keyakinan irasional terkait dengan hal-hal yang dianggap subjek gagal. 
Permasalahan yang terjadi pada subjek dapat dijelaskan dengan teori ABC Albert Ellis. Ellis berpendapat bahwa keyakinan irasional yang dimiliki individu tentang masalahnya menumbuhkan emosi negatif dan perilaku maladaptif. Ellis menggunakan pendekatan $\mathrm{ABC}$ untuk menjelaskan penyebab masalah pada individu. A (activating event) merupakan kejadian yang menggerakkan. B (belief) merupakan keyakinan individu tentang suatu kejadian. Sedangkan C (consequences) merupakan konsekuensi atau reaksi emosional seseorang. Ellis menekankan bahwa konsekuensi (C) dari peristiwa (A) tidak akan menjadi sebuah tekanan emosional jika tidak ada keyakinan irasional (B) yang memediasinya. Sifat keyakinan irasional yang menuntut (kecenderungan untuk memaksakan "keharusan" dan "seharusnya") pada diri sendiri (Corey, 2013).

Keyakinan irasional terdiri dari empat kategori, diantaranya adalah (1) demandingness (menuntut), melibatkan kata "harus atau seharusnya"; (2) awfulizing, yakni mengevaluasi suatu peristiwa secara ekstrim sebagai sesuatu yang sangat buruk dari seharusnya; (3) low frustration tolerance, yakni keyakinan dimana seseorang tidak bisa toleran terhadap suatu situasi; dan (4) global evaluation, yakni menilai negatif secara umum, seperti menyalahkan atau terlalu kritis, terhadap diri sendiri, orang lain, maupun hidup atau dunia secara keseluruhan (David et al., 2005).

Pada penelitian ini, subjek memiliki kebutuhan yang besar akan kasih sayang, namun tidak mendapatkan perhatian dan kasih sayang tersebut dari orang tua terutama ayah sejak ia masih kecil. Erikson berpendapat bahwa usia 0-2 tahun adalah titik awal pembentukan kepribadian anak Chung (2018). Bayi belajar mempercayai orang lain agar kebutuhan-kebutuhan dasarnya terpenuhi. Peran ibu atau orang-orang terdekat seperti pengasuh yang mampu menciptakan keakraban dan kepedulian dapat mengembangkan kepercayaan dasar. Persepsi yang salah pada diri anak tentang lingkungannya karena penolakan dari orangtua atau pengasuh mengakibatkan bertumbuhnya perasaan tidak percaya sehingga anak memandang dunia sekelilingnya sebagai tempat yang jahat.

Subjek cenderung sering dibandingkan dengan adiknya sejak kecil. Orang tua, terutama ayah, dan beberapa temannya juga sering mengejek fisik subjek sehingga cenderung mudah merasa tidak percaya diri dan sering membandingkan dirinya dengan orang lain. Berdasarkan hasil asesmen juga diketahui bahwa subjek memiliki konsep diri yang kurang baik dan mudah merasa tidak percaya diri. Hal ini menjadi semakin buruk ketika subjek juga cenderung kurang terampil dalam memecahkan masalah sehingga membuatnya cenderung mudah mengambil langkah yang kurang tepat dan merugikan atau merusak dirinya sendiri.

Oleh karena itu, ketika terdapat suatu peristiwa pemicu (A) dimana subjek merasa dirinya sudah cukup umur dan sangat ingin memiliki kekasih yang dapat menyayanginya serta sudah berusaha untuk mendapatkannya namun tidak kunjung ia dapatkan, maka subjek akan memunculkan keyakinan irasional. Adapun diantaranya adalah (1) menuntut dirinya harus segera mendapatkan kekasih (demandingness), (2) berpikir bahwa tidak memiliki kekasih adalah hal yang buruk dan memalukan (awfulizing), (3) berpikiran bahwa fisiknya yang kurang menarik menyebabkan tidak ada laki-laki yang menginginkannya (self-downing) meskipun ia tidak pernah mendapatkan bukti dari keyakinannya tersebut, dan (4) membandingbandingkan dirinya dengan orang lain yang berganti-ganti kekasih sedangkan ia tidak bisa (others-downing).

Keyakinan irasional tersebut akhirnya menimbulkan konsekuensi (C) yakni sering merasa sedih, kosong, tidak memiliki harapan, merasa tidak berharga, sulit berkonsentrasi dan sulit mengambil keputusan, penurunan motivasi dan minat, sering merasa kelelahan, beberapa kali berpikir bunuh diri setiap laki-laki yang ia sukai menjauh, serta mulai merokok untuk menghilangkan kesedihannya. Erikson Chung (2018) berpendapat bahwa usia 20-40 tahun merupakan tahap keintiman atau keakraban vs keterasingan atau kesendirian. Pada tahap ini kekuatan dasar yang dibutuhkan ialah "kasih" karena muncul konflik antara keintiman atau keakraban versus keterasingan atau kesendirian. Agen sosial pada tahap ini ialah kekasih, suami atau istri termasuk juga sahabat yang dapat membangun suatu bentuk persahabatan sehingga tercipta rasa cinta dan kebersamaan. Bila kebutuhan ini tidak terpenuhi, maka muncul perasaan kesepian, kesendirian dan tidak berharga.

Individu yang tidak mampu menerima diri karena memiliki kepercayaan-kepercayaan irasional mengenai diri yang digunakan individu untuk mendefinisikan dirinya secara global (Bernard et al., 2013). Hal ini sesuai dengan kondisi subjek dimana keyakinan-keyakinan irasionalnya membuat ia mendefinisikan dirinya secara global bahwa tidak ada laki-laki yang ingin menjadi kekasihnya karena kelemahan yang dimilikinya. Oleh karena itu, subjek perlu diberikan penanganan untuk mengurangi bahkan mengganti keyakinan irasionalnya menjadi keyakinan yang lebih rasional atau lebih positif sehingga masalah konsekuensi negatif berubah menjadi konsekuensi yang positif menggunakan terapi rasionalemotif perilaku menurut Albert Ellis (Corey, 2013).

\section{Diagnosis dan Prognosis}

Berdasarkan hasil asesmen dan rujukan yang ada di Diagnostic and Statistical Manual of Mental Disorder Fifth Edition (DSM-V) (American Psychiatric Association, 2013), maka dapat ditegakkan diagnosis bahwa subjek memenuhi kriteria diagnostik: 296.22 (F32.1) Major Depressive Disorder kategori sedang. Alasan subjek didiagnosa mengalami depresi ialah karena subjek memenuhi enam dari minimal lima simtom (total sembilan simtom) yang harus dipenuhi pada kriteria A. Tingkat depresi F diketahui dari hasil skala BDI-II dimana subjek memiliki skor 26 dan 
masuk dalam kategori depresi sedang. Berdasarkan WHODAS 2.0, taraf keberfungsiannya yakni 2,92 dan masuk dalam kategori sedang. Hal tersebut menunjukkan bahwa subjek masih dapat berfungsi cukup baik dalam melakukan kegiatan sehari-hari.

Terapis memperkirakan keberhasilan subjek dalam melakukan intervensi adalah baik. Hal ini dikarenakan subjek berkomitmen ingin segera menyelesaikan masalahnya. Subjek dapat diajak untuk berdiskusi dan tidak berusaha menyangkal masalahnya sehingga ia mampu memahami seluruh jalannya terapi yang diberikan. Saat ini, lingkungan subjek juga baik dimana ibu dan banyak teman subjek sering mendukungnya dengan menyatakan bahwa subjek memiliki banyak kelebihan. Gangguan subjek juga tidak disebabkan oleh faktor genetik dan tidak adanya penggunaan obat-obatan yang mengandung zat adiktif. Hasil WHODAS juga menunjukkan bahwa keberfungsian F dalam aktifitas sehari-hari masih cukup baik sehingga mampu melakukan intervensi dengan cukup baik.

\section{Intervensi}

Intervensi yang diberikan dalam kasus ini adalah terapi rasional-emotif perilaku. Terapi ini menekankan pada pemikiran, emosi dan tindakan yang secara simultan. Perasaan-perasaan dipersepsikan atas situasi yang spesifik. Terapi ini mengatasi segenap manifestasi dari depresi, kesakitan, kehilangan rasa berharga dan kebencian (Corey, 2013). Target intervensi ialah untuk menurunkan tingkat depresi subjek yang disebabkan oleh keyakinan irasional. Keyakinan rasional baru yang diharapkan ialah subjek tidak lagi terlalu menuntut dirinya memiliki kekasih, berpikiran bahwa tidak memiliki kekasih adalah hal yang wajar dan tidak memalukan, tidak berpikir bahwa fisiknya yang kurang menarik menyebabkan tidak ada laki-laki yang menginginkannya sehingga subjek bisa menerima kekurangan yang ia miliki, dan tidak lagi membandingkan dirinya dengan orang lain yang memiliki kekasih.

Dalam terapi rasional-emotif perilaku, dilakukan disputing (D) setelah A-B-C untuk membantu klien menantang keyakinan irasionalnya. Ada tiga komponen dari proses ini yakni: mendeteksi, mendebatkan, dan mendiskriminasi. Pada akhirnya klien akan belajar membedakan keyakinan irasional dan keyakinan rasional. Restrukturisasi kognitif adalah teknik sentral terapi kognitif yang mengajarkan orang bagaimana meningkatkan diri dengan mengganti keyakinan irasional dengan keyakinan rasional. Akhirnya setelah disputing (D) berhasil, maka muncul efek (E) yakni sistem kepercayaan yang baru dan efektif terdiri dari mengganti pikiran yang tidak sehat menjadi lebih sehat. Jika berhasil melakukannya, maka juga akan muncul serangkaian (F) perasaan baru (Corey, 2013).

Terapi rasional-emotif perilaku dilaksanakan dengan metode memperdebatkan keyakinan irasional dimana terapis yang secara aktif memperdebatkan keyakinan irasional klien dan mengajari klien bagaimana melakukannya dengan tantangannya sendiri. Klien membahas "keharusan" tertentu, "mutlak-harus," atau "seharusnya" sampai klien tidak lagi memegang keyakinan irasional itu, atau setidaknya sampai berkurang kekuatannya (Corey, 2013). Terapi rasional-emotif perilaku memunculkan perubahan yang lebih mendalam dibandingkan terapi kognitif karena (a) dapat membuat klien menerima dirinya tanpa syarat; (b) mengurangi masalah sekunder, seperti mengkritisi diri sendiri karena memiliki masalah; (c) dan fokus pada sikap klien yang selalu menuntut dirinya yang merupakan keyakinan dasar pada kasus depresi (David et al., 2005).

Terapi yang baik ialah terapi yang efisien dan cepat. Klien belajar bagaimana mengaplikasikan teknik terapi pada masalah di masa yang akan datang. Ciri khas yang membuat terapi ini menjadi terapi yang singkat ialah terapi tersebut menggunakan pendekatan self-help. Keyakinan irasional klien diperdebatkan selama sesi dan klien diajarkan bagaimana memperdebatkan keyakinan irasionalnya sendiri selama 1 sampai 10 sesi dan kemudian dipraktikan di rumah (Corey, 2013).

David et al. (2004) menjelaskan prosedur pelaksanaan terapi rasional-emotif perilaku sebagai berikut: (1) Pengenalan intervensi (membangun hubungan terapeutik, menjelaskan konsep terapi, harapan dalam intervensi); (2) mengidentifikasi masalah dengan menggunakan pendekatan ABC (DEF) dari model terapi; (3) membantu klien melihat hubungan diantara masalah; (4) memperdebatkan atau memperlemah keyakinan irasional dan memperkuat keyakinan rasional klien; dan (5) memberikan klien tugas rumah untuk melatih klien mengubah keyakinan irasionalnya sendiri. Adapun sesi dalam terapi rasional-emotif perilaku yang dilakukan dengan mengacu pada prosedur terapi yang disampaikan oleh David et al. (2004) pada kasus ini adalah:

Sesi I: Pengantar intervensi dan relaksasi. Pada sesi ini terapis dan subjek melakukan kesepakatan dan kontrak dalam proses intervensi yang akan dilaksanakan seperti jumlah sesi dan durasi setiap sesinya. Terapis juga menjabarkan hasil asesmen secara umum kepada subjek. Terapis menjelaskan model dan prosedur intervensi yang akan dilaksanakan serta menanyakan persetujuan subjek. Selanjutnya, terapis mengajarkan subjek relaksasi dengan teknik pernafasan untuk diterapkan setiap kali keyakinan irasionalnya muncul. Teknik ini diajarkan sebagai bekal subjek dikemudian hari meskipun intervensi telah selesai

Sesi II: Identifikasi dan memperdebatkan keyakinan irasional, serta pemberian tugas. Pada sesi ini, terapis menunjukkan pada subjek bahwa masalah yang dihadapinya berkaitan dengan keyakinannya yang irasional. Terapis bersama dengan subjek mengidentifikasi keyakinan irasional dan terapis berusaha memperlihatkan mengapa terjadinya keyakinan irasional serta menunjukkan masalah sebagai hasil dari keyakinan irasional dengan menggunakan konsep A-B-C. Kemudian terapis berusaha memperdebatkan keyakinan irasional tersebut. Pada tahap ini, dilakukan konfrontasi dan menentang 
keyakinan-keyakinan irasional tersebut. Keyakinan irasional yang diperdebatkan ialah (a) selalu menuntut dirinya untuk segera mendapatkan kekasih;(b) Berpikiran bahwa tidak memiliki kekasih ialah suatu hal yang buruk dan memalukan; (c) Merasa bahwa fisiknya yang kurang menarik menyebabkan tidak ada laki-laki yang menyukainya meskipun ia sudah berusaha mencari; (d) Menyalahkan dan membandingkan dirinya dengan orang lain yang memiliki kekasih sedangkan ia tidak. Selain itu, terapis juga memperlihatkan berita atau video yang berkaitan dengan kisah nyata beberapa perempuan yang memiliki fisik mirip dengan subjek namun mendapatkan laki-laki yang dapat menerima mereka apa adanya.

Pada akhirnya, subjek diberikan tugas rumah untuk melatih dirinya memperdebatkan keyakinan-keyakinan irasional yang muncul setiap harinya. Subjek diberikan lembar yang terdapat tabel dengan kolom peristiwa pemicu (A), keyakinan-keyakinan irasional yang muncul (B), apa konsekuensi yang ia dapatkan atau rasakan (C), bagaimana ia mengubahnya menjadi keyakinan yang lebih rasional (D), bagaimana keyakinan rasional baru yang ia miliki (E), dan bagaimana perasaan atau perilakunya yang baru setelah ia berhasil mengubahnya menjadi keyakinan rasional (F). Selain itu, subjek juga diminta untuk mencari kata-kata mutiara yang ia sukai dan paling berhasil membuat perasaannya lebih lega atau lebih baik dan memotivasi dirinya. Terapis meminta subjek untuk membawa kata-kata mutiara tersebut pada pertemuan selanjutnya dan membahasnya bersama dengan terapis.

Sesi III: Evaluasi I tugas rumah. Terapis Pada sesi ini, terapis bersama-sama dengan subjek mendiskusikan hasil tugas rumah yang sudah dilakukan dan menanyakan hambatan yang dirasakan subjek serta mengatasinya bersama-sama. Subjek menyatakan bahwa dirinya sudah mencoba melakukan tugas rumah yang diberikan. Setiap hari ada saja keyakinan irasional yang muncul mengenai dirinya. Ia menyatakan bahwa ia merasa emosinya menjadi lebih positif ketika ia mempraktikan tugas rumah yang telah diberikan setiap harinya. Terapis memberikan penguatan kepada subjek bahwa usaha yang telah dilakukan sudah sangat bagus dan memintanya untuk terus melakukannya setiap hari.Terapis menguatkan keyakinan positif subjek tersebut dan memintanya untuk terus melakukan tugas rumahnya tersebut dan mencari sendiri video motivasi yang paling ia sukai dan akan dibahas bersama-sama pada pertemuan selanjutnya.

Sesi IV: Evaluasi II tugas rumah dan terminasi. Pada sesi ini, terapis bersama-sama dengan subjek mendiskusikan hasil tugas rumah yang sudah dilakukan dan menanyakan hambatan yang dirasakan subjek serta mengatasinya bersama-sama. Subjek menyatakan bahwa keyakinan irasionalnya sudah tidak muncul setiap hari. Sejak pertemuan sebelumnya, keyakinan irasional subjek hanya muncul dua kali, namun ia berusaha untuk melakukan relaksasi dan memperdebatkan keyakinan irasionalnya kembali seperti biasa. Ia juga membaca kembali kata-kata yang ia sukai. Akhirnya ia merasa lebih lega dan sudah jarang menangis secara tiba-tiba lagi. Subjek juga memberi tahu terapis bahwa ia sudah menemukan video motivasi yang membuatnya semangat

Sesi V: Tindak lanjut. Sesi ini dilakukan dua minggu setelah intervensi berakhir untuk melihat perkembangan subjek apakah tingkat depresi subjek menurun yang disebabkan oleh keyakinan rasionalnya yang baru atau tidak. Subjek menyatakan bahwa saat ini ia sudah mulai melakukan aktivitas seperti biasa dengan lebih baik. Subjek berusaha mengerjakan skripsinya yang tertunda meskipun harus berusaha keras melawan rasa malasnya. Kemudian, sudah lebih bisa menerima kekurangan yang ia miliki dan tidak terlalu memaksakan dirinya untuk mendapatkan kekasih dalam waktu dekat. Subjek mengaku terkadang masih ada pikiran-pikiran negatif yang muncul dalam kehidupan sehari-hari, namun ia tetap mencoba untuk mempraktikan teknik-teknik mengubah pemikiran negatif yang telah dipelajari selama intervensi dalam kehidupannya sehari-hari dan ia rasa sangat membantu. Subjek juga mulai menyusun rencana kedepan beserta langkah-langkah praktisnya sehingga ia merasa bersemangat dan tidak terlalu berfokus pada hal-hal negatif di sekitarnya.

\section{Hasil dan Pembahasan}

\section{Hasil}

Intervensi yang dilakukan mendapatkan hasil sesuai dengan target dimana tingkat depresi subjek menurun yang disebabkan oleh keyakinan irasional subjek berubah menjadi keyakinan rasional. Berdasarkan hasil BDI-II, diketahui bahwa subjek mengalami penurunan tingkat depresi sebanyak delapan poin dimana sebelum melakukan intervensi subjek memiliki skor BDI-II sebesar 26 (kategori depresi sedang) kemudian setelah melakukan intervensi menurun menjadi 18 (depresi ringan).

Perubahan juga dapat dilihat secara kualitatif dimana keyakinan irasional subjek berubah menjadi keyakinan yang lebih rasional selama proses intervensi. Ia sudah tidak terlalu menuntut dirinya untuk segera memiliki kekasih. Ia juga sudah mampu berpikir bahwa tidak memiliki kekasih adalah sesuatu yang wajar dan tidak memalukan. Ia juga menyadari bahwa ia memang memiliki tubuh yang gemuk dan kulit berwarna coklat, namun itu bukan hal yang besar dan ia juga memiliki banyak kelebihan. Selain itu, ia juga sudah tidak mempermasalahkan jika teman dan adiknya berganti kekasih, mungkin mereka memang telah menemukan orang yang dapat menerima mereka, dan subjek yakin bahwa ia juga akan menemukan orang yang dapat menerimanya.

Subjek merasakan efek yang positif dimana ia tidak mudah bersedih atau menangis lagi dan lebih semangat menyelesaikan skripsi. Selain itu, subjek juga dengan mudah mengingat prosedur relaksasi dan lancar mempraktikan relaksasi untuk membantunya dalam mereduksi 
keyakinan irasionalnya. Hasil intervensi membuat subjek menyadari bahwa keyakinan irasionalnya membuat dirinya selama ini sering merasa sedih dan tidak bersemangat serta sulit berkonsentrasi. Subjek juga bisa lebih menerima dirinya sendiri dan berniat untuk mengembangkan kelebihan yang ia miliki. Dari hasil yang didapatkan tidak lepas dari komitmen subjek dalam menjalankan terapi ini. Komitmen subjek pada terapi sangat tinggi dengan proses usaha yang dilakukan untuk memperdebatkan keyakinan irasionalnya dan mengembangkan keyakinan rasionalnya. Beberapa teman subjek juga mendukungnya dan turut menguatkan dengan menyatakan bahwa subjek cantik dan memiliki banyak kelebihan.

\section{Pembahasan}

Berdasarkan hasil intervensi tersebut, dapat disimpulkan bahwa terapi rasional-emotif perilaku dapat mengatasi masalah subjek yakni mengurangi keyakinan irasionalnya dan mengembangkan keyakinan rasional yang sejalan dengan menurunnya gejala depresi yang dialami subjek. Hal ini sesuai dengan hasil penelitian yang dilakukan oleh Zhaleh et al. (2014) yakni terapi rasional-emotif perilaku efektif untuk mengurangi depresi dengan mengidentifikasi keyakinan irasional, keharusan dan aturan, mengidentifikasi keyakinan dasar, menantang keyakinan irasional, dan meningkatkan kepercayaan diri individu.

Penelitian yang dilakukan oleh Santosa, Purwono, dan Kumalasari (2015) juga menunjukkan bahwa terapi rasional-emotif perilaku secara efektif dapat menurunkan derajat simtom-simtom depresi yang dialami oleh klien. Hal tersebut terlihat dari perubahan derajat emosi negatif, pikiran negatif, serta kondisi fisik dan perilaku yang terkait dengan simtom depresi tersebut. Pemberian terapi ini juga dapat memberikan perubahan pada keyakinan yang dimiliki klien sehingga tidak terpaku pada keyakinan irasional ketika mengalami suatu kejadian.

Subjek juga bisa lebih menerima kondisi fisiknya dan berkomitmen untuk lebih berfokus pada kelebihan yang ia miliki dibandingkan berfokus pada kelemahannya. Hal tersebut didukung oleh hasil penelitian yang dilakukan oleh Cunningham \& Turner (2016) bahwa terapi rasionalemotif perilaku dapat meningkatkan penerimaan diri klien dimana klien dapat menerima kegagalan yang ia hadapi dan tidak mudah menyalahkan dirinya sendiri.

Penerimaan diri subjek selama dan setelah intervensi diperkuat oleh teori yang dikemukakan oleh Ellis dimana ia menyatakan bahwa terapi rasional-emotif perilaku memiliki efikasi yang melebihi terapi kognitif lainnya karena mendorong perubahan yang lebih mendalam dengan cara: (1) mengarahkan klien untuk mencapai penerimaan diri tanpa syarat; (2) fokus secara eksplisit untuk mengatasi permasalahan sekunder seperti depresi karena depresi itu sendiri; dan (3) secara eksplisit membahas mengenai tuntutan yang bersifat absolut terhadap diri sendiri, orang lain, dan dunia yang nampaknya merupakan keyakinan dasar yang terlibat dalam dinamika depresi (David et al., 2008) .

\section{Simpulan}

Terapi rasional-emotif perilaku terbukti efektif untuk mengubah keyakinan irasional subjek menjadi lebih rasional atau positif. Hal tersebut ditandai dengan subjek yang tidak lagi terlalu memaksakan dirinya untuk mendapatkan kekasih, berpikir bahwa tidak memiliki kekasih adalah hal yang wajar, lebih bisa menerima kekurangannya dan lebih berfokus pada kelebihan yang ia miliki, serta sudah mampu menerima bahwa adik dan teman-temannya memiliki kekasih dan menyadari bahwa suatu saat ia juga akan menemukan orang lain yang bisa menerima dirinya apa adanya. Hal tersebut juga didukung oleh hasil skala BDI-II dimana skor dan tingkat depresi subjek mengalami penurunan yang signifikan.

\section{Referensi}

American Psychiatric Association. (2013). Diagnostic and statistical manual of mental disorders fifth edition. Washington DC: American Psychiatric Publishing

Bernard, M. E., Hoffman, L. A, Lopez, A. J., \& Moats, M. (2013). The strength of self-acceptance: theory, practice and research. London: Springer.

Chamberlain, J. M., \& Haaga, D. A. F. (2001). Unconditional self-acceptance and psychological health. Journal of Rational-emotive \& Cognitive Behavior Therapy,19. (3), 163-176. http://10.21465/2016-SP-191-06

Chung, D. Y. (2018). The eight stages of psychosocial protective development: Developmental psychology. Journal of Behavioral and Brain Science, 8., 369-398.

Corey, G. (2013). Theory and practice of counseling and psychotherapy (9th ed.). Amerika: Cengage Learning

Cunningham, R., \& Turner, M. J. (2016). Using rational emotive behavior therapy (REBT) with mixed martial arts (MMA) athletes to reduce irrational beliefs and increase unconditional self-acceptance. Journal of Rational-Emotive and Cognitive-Behavior Therapy, 34. (4), 289-309. http://dx. doi.org/10.1007/s10942-016-0240-4

David, D., Kangas, M., Schnur, J. B., \& Montgomery, G. H. (2004). REBT depression manual: Managing depression using rational emotive behavior therapy. Babes-Bolyai University (BBU), Romania.

David, D. Szentagotai, A., Kallay, E., \& Macavei, B. (2005). A synopsis of rational-emotive behavior therapy (REBT): Fundamental and applied research. Journal of RationalEmotive \& Cognitive-Behavior Therapy, 3., 175-221. http: //10.1007/s10942-005-0011-0

David, D., Szentagotai, A., Lupu, V., \& Cosman, D. (2008). Rational emotive behavior therapy versus cognitive therapy versus pharmacotherapy in the treatment of major depressive disorder: Mechanisms of change analysis. Psychotherapy Theory, Research, Practice, Training, 45. (4), 523-538. .http: //10.1037/a0014332 
Forgeard, M. J. C., Haigh, E. A. P., Beck, A. T., Davidson, R. J., Henn, F. A., Maier, S. F., \& Seligman, M. (2012). Beyond depression: Toward a process-based approach to research, diagnosis, and treatment. Clinical Psychology: Science and Practice, 18., 275-299.http://doi:10.1111/j.1468-2850.2011. 01259.x

Kurniawan, Y., \& Noviza. (2017). Psikoterapi interpersonal untuk menurunkan gejala depresi pada perempuan korban kekerasan dalam rumah tangga. Jurnal Psikologi dan Kesehatan Mental, 2. (2), 96-102.http://dx.doi.org/10.20473/ jpkm.V2I22017.96-102

Pratt,L.A., \& Brody, D. J. (2008). Depression in the united states household population, 2005-2006. NCHS Data Brief, Number 7. Diambildarihttp://www.cdc.gov/nchs/data/ databriefs/db07.htm
Santosa, A., Purwono, U., \& Kumalasari, A. (2015). Efektivitas rational emotive behavior therapy (rebt) untuk menurunkan derajat simtom depresi pada pasien jantung. Artikel Ilmiah Universitas Padjajaran.

Zhaleh, N., Zarbakhsh, M., \& Faramarzi, M. (2014). Effectiveness of rational-emotive behavior therapy on the level of depression among female adolescents. Journal of Applied Environmental and Biological Science, 4. (4), 102-107.https://citeseerx.ist.psu.edu/viewdoc/download? doi=10.1.1.1060.2297\&rep=rep1\&type $=$ pdf 